\title{
RADIOPROTECTIVE EFFECTS OF QUERCETIN AND ETHANOLIC EXTRACT OF PROPOLIS IN GAMMA-IRRADIATED MICE
}

\author{
Vesna BENKOVIĆ ${ }^{1}$, Anica HORVAT KNEŽEVIĆ ${ }^{1}$, Domagoj ĐIKIĆ ${ }^{1}$, Duje LISIČIĆ ${ }^{1}$, \\ Nada ORŠOLIĆ ${ }^{1}$, Ivan BAŠIĆ ${ }^{1}$, and Nevenka KOPJAR ${ }^{2}$ \\ Department of Animal Physiology, Faculty of Science, University of Zagreb ${ }^{1}$, Institute for \\ Medical Research and Occupational Health', Zagreb, Croatia
}

Received in August 2008

Accepted in March 2009

\begin{abstract}
The aim of this study was to assess radioprotective effects of quercetin and the ethanolic extract of propolis (EEP) in CBA mice exposed to a single radiation dose $4 \mathrm{~Gy}\left({ }^{60} \mathrm{Co}\right)$. The mice were treated with $100 \mathrm{mg} \mathrm{kg}^{-1}$ quercetin or EEP a day for three consecutive days either before (pre-treatment) or after gamma-irradiation (therapy). Leukocyte count was determined in blood drawn from the tail vein, and DNA damage in leukocytes was assessed using the alkaline comet assay. Genotoxic effects of the test compunds were also evaluated in non-irradiated mice. The levels of radioprotection provided by both test compounds were compared with those established in mice that were given chemical radioprotector S-(2Aminoethyl)isothiouronium bromide hydrobromide (AET). Mice that received pre-treatment were less sensitive to irradiation. Mice given the post-irradiation therapy showed a slight but not significant increase in total leukocyte count over irradiated negative control. Quercetin showed better protective properties than EEP in both pre-treatment and therapy, and activated a higher number of leukocytes in non-irradiated mice. The alkaline comet assay suggests that both natural compounds, especially when given as pre-treatment, protect against primary leukocyte DNA damage in mice. At tested concentrations, EEP and quercetin were not genotoxic to non-irradiated mice. AET, however, caused a slight but not significant increase in DNA damage. Although the results of this study show the radioprotective potential of the test compounds, further investigation is needed to clarify the underlying protection mechanisms.
\end{abstract}

KEY WORDS: AET, DNA damage, EEP, flavonoid, honey bee products, leukocyte, radioprotection

Even though a number of substances have been studied for radioprotective effects, there is no ideal protective strategy to be universally employed in occupational and therapeutic settings involving exposure to ionising radiation.

Ionising radiation mostly affects DNA, either directly or by generating toxic free radicals, and induces single strand breaks, double strand breaks, oxidative damage to sugar and base residues, chromosomal aberrations, and various mutations (1). Nevertheless, it is widely applied in the treatment of many malignant diseases, but it necessarily involves exposure of non-target cells in treated patients.

As radiation effects do not discriminate between normal and malignant cells and tissues, investigations have been conducted to find effective and nontoxic radioprotective compounds and to improve radiotherapy. Because radiation-induced cell damage is primarily attributed to the harmful effects of free radicals, molecules with radical scavenging properties are particularly promising as radioprotectors $(2$, $3)$. One such compound common to oncological 
practice is amifostine (S-2-(3-amino-propylamino) ethylphosphorothioic acid), but it is expensive, must be given intravenously, and has undesirable side effects (4).

To overcome harmful effects of synthetic compounds, many naturally occurring substances have been studied as candidates for effective radioprotection. These include polyphenols and honeybee products such as propolis and bee venom. The awareness of their radioprotective properties has increased over the last decade, and their effects have extensively been studied in vitro and in vivo (5-12). Polyphenols are abundant micronutrients in human diet and include hydroxybenzoic acids, hydroxycinnamic acids, anthocyanins, proanthocyanidins, flavonols, flavones, flavanols, flavanones, isoflavones, stilbenes, and lignans (13). These compounds originate from the secondary metabolism of plants and protect against photosynthetic stress and reactive oxigen species (ROS), and help wounds to heal faster (14). Their antioxidant activity is mainly based on their ability to scavenge free radicals. They can also enhance the function of the endogenous antioxidant enzyme systems such as superoxide dismutase, catalase, glutathione peroxidase, and glutathione reductase (15). These antioxidant effects may also be a result of a combination of radical scavenging and interaction with enzyme functions (16).

Polyphenol quercetin is a flavonoid abundant in fruits, vegetables, olive oil, red wine, tea, and propolis. Its daily intake through food is about $16 \mathrm{mg}$ (17). It has shown the highest antioxidant potential of all flavonoids (18), but can also produce reactive oxigen radicals (19-21). Even though the findings about its mutagenicity and toxicity are contradictory, the International Agency for Research on Cancer (IARC) has not classified quercetin as carcinogenic to humans (22). Most harmful effects of quercetin have been observed in vitro. It is believed that the absence of its carcinogenic effect in vivo is mainly owed to its metabolic inactivation after apsorption (23).

Propolis (bee glue) is an adhesive resinous substance produced by honey bees from leaf, bud, flower, and tree sap. The wide variety of its biological properties make it ever more interesting for use in medicine. Propolis and its active polyphenolic constituents have shown antibacterial (24), antioxidant (25), and prooxidant properties (26). Propolis also affects immunity $(27,28)$ and acts against cell proliferation and tumors in vitro (29) and in vivo (30-33).
Our earlier study showed that both water-soluble derivate of propolis (WSDP) and ethanolic extract of propolis (EEP) extended the survival of mice irradiated with a single lethal dose ( 9 Gy) of gammairradiation (10). In another study, WSDP and several water soluble polyphenols showed radioprotection against gamma-irradiation with 4 Gy and 9 Gy (11). EEP and quercetin were also confirmed as useful protectors in a study on mice irradiated with $9 \mathrm{~Gy}$ (12). This study continues our research, and its aim was to establish the radioprotective effects of EEP and quercetin given as pre-treatment or therapy to mice irradiated with a lower dose of gamma-irradiation, i. e. $4 \mathrm{~Gy}$, which is more realistic for human exposure. The efficiency of the test compounds was evaluated on the cellular level by determining leukocyte count and cell damage using the alkaline comet assay.

\section{MATERIALS AND METHODS}

\section{Chemicals and reagents}

Unless specified otherwise, chemicals and reagents used were purchased from Sigma Chemical Co., St. Louis, MO, USA.

\section{Propolis}

In this and our previous studies we used raw Croatian propolis. It belongs to the poplar-type of propolis, characteristic for the northern hemisphere (12). Recent spectrophotometric analyses showed that its ethanolic extract contained $84.40 \%$ of total polyphenols, of which $1.6 \%$ were flavones and flavonols, $38.60 \%$ flavanones and dihydroflavonols, and $40.20 \%$ total flavonoids (10).

The propolis was collected by scraping it off bee hive frames. Before use it was kept desiccated at room temperature. Ethanolic extract of propolis (EEP) was prepared using the method described by Kosalec et al. (34). Briefly, raw propolis ( $10 \mathrm{~g})$ was crushed into small pieces in a mortar and mixed vigorously with $50 \mathrm{~mL}$ of $80 \%$ ethanol at $(37 \pm 1){ }^{\circ} \mathrm{C}$ for $48 \mathrm{~h}$. Eightypercent ethanol was prepared by diluting $96 \%$ ethanol (Kemika, Croatia) with sterile bidistilled water. The mixture of propolis and ethanol was filtered through Whatman No. 4 paper, lyophilised, and kept in dark at $+4{ }^{\circ} \mathrm{C}$.

EEP was injected to mice intraperitoneally (ip) at a daily dose of $100 \mathrm{mg} \mathrm{kg}^{-1}$ body weight for three consecutive days before (pretreatment) or after 
irradiation (therapy). The final concentration of ethanol in EEP injected to mice was less than or equal to $1 \%$. The same concentration of ethanol was given to mice in the solvent control group.

\section{Quercetin}

Quercetin dihydrate, -3,3',4',5,7-pentahydroxyflavone dihydrate (Fluka, BioChemica, Switzerland) was dissolved in ethanol and further dilutions were made in sterile bidistilled water. Just like EEP, quercetin was also injected to mice at a daily dose of $100 \mathrm{mg} \mathrm{kg}^{-1}$ body weight for three consecutive days before or after irradiation. The final concentration of ethanol in quercetin solution injected to mice was less than or equal to $1 \%$.

\section{S-(2-Aminoethyl)isothiouronium bromide hydrobromide (AET)}

AET $\left(\mathrm{C}_{3} \mathrm{H}_{9} \mathrm{~N}_{3} \mathrm{~S} \cdot 2 \mathrm{HBr}\right)$ was used as positive control, since earlier studies on $\mathrm{X}$-irradiated mice verified its capacity to extend the survival rate in the dose range of 8 Gy to 11 Gy (35). Before use, it was dissolved in sterile bidistiled water and given to mice intraperitoneally at a dose of $281 \mathrm{mg} \mathrm{kg}^{-1}$ body weight before or after irradiation.

The doses of all compounds were based on the positive results of our earlier studies and on reports of other authors (10-12, 35-37).

\section{Animals}

The study was perfomed on male, three-monthold CBA mice ( $\mathrm{N}=75$ ) weighing from $20 \mathrm{~g}$ to $22 \mathrm{~g}$. The animals were kept in Plexiglass ${ }^{\circledR}$ cages under controlled conditions [room temperature $(22 \pm 1)^{\circ} \mathrm{C}$, $50 \%$ to $70 \%$ humidity, 12 -h light : 12 -h dark cycle], received a standard diet for laboratory rodents (4 RF 21, Mucedola s.r.l., Italy), and had free access to water. The mice were randomly distributed in groups of five and were deprived of food for $24 \mathrm{~h}$ before the experiment. Animal studies were carried out in accordance with the Croatian Animal Welfare Act (38) and the Guide for the Care and Use of Laboratory Animals issued by the US Institute for Laboratory Animal Research (39).

\section{Experimental design}

Three independent experiments were performed. In the first, mice were pre-treated with test compounds for three consecutive days and then gamma-irradiated with a single dose of $4 \mathrm{~Gy}$. In the second experiment, mice were first irradiated with a single dose of $4 \mathrm{~Gy}$ and then received intraperitoneal doses of the tested compounds for three consecutive days (therapy). In the third experiment, the test compounds were given to non-irradiated mice following the same design. Appropriate control groups were also selected and handled in the same manner. Negative control was given saline, solvent control $1 \%$ ethanol, and positive control chemical radioprotector AET. All (treated and control) groups included five mice each.

In the first experiment, leukocyte count and the alkaline comet assay were performed on blood samples taken 30 min after irradiation, while in second and third experiments blood samples were taken after finishing the three-day treatment.

\section{Irradiation}

Five mice were whole-body irradiated at a time using a ${ }^{60} \mathrm{Co}$ gamma-ray source (situated at the Ruđer Bošković Institute, Zagreb, Croatia). Sourceto-skin distance was $291 \mathrm{~cm}$, and the dose rate was $0.0233 \mathrm{~Gy} \mathrm{~s}^{-1}$. It took $173 \mathrm{~s}$ to achieve the total absorbed dose of $4 \mathrm{~Gy}$.

\section{METHODS}

\section{Collection of blood}

Blood samples were drawn from the tail vein and processed for analysis immediately after collection.

\section{Peripheral whole blood leukocyte count}

Total peripheral blood leukocytes were counted using a haemocytometer (40).

\section{The comet assay}

The comet assay was carried out under alkaline conditions, as described by Singh et al. (41). Two slides per animal were prepared. Agarose gels were prepared on fully frosted slides coated with $1 \%$ and $0.6 \%$ normal melting point (NMP) agarose. Samples of peripheral blood $(5 \mu \mathrm{L})$ were mixed with $0.5 \%$ low melting point (LMP) agarose, placed on the slides, and covered with a layer of $0.5 \%$ LMP agarose. The slides were immersed for $2 \mathrm{~h}$ in freshly prepared ice-cold lysis solution $\left(2.5 \mathrm{~mol} \mathrm{~L}^{-1} \mathrm{NaCl}\right.$, $100 \mathrm{mmol} \mathrm{L}^{-1}$ ethylenediamine-tetraacetic acid disodium salt ( $\mathrm{Na}_{2}$ EDTA), $10 \mathrm{mmol} \mathrm{L}^{-1}$ Tris- $\mathrm{HCl}, 1 \%$ Na-sarcosinate, $\mathrm{pH} 10)$ with $1 \%$ Triton X-100 and $10 \%$ dimethyl sulfoxide (Kemika, Zagreb, Croatia). 
Denaturation and electrophoresis were carried out in a freshly prepared electrophoresis buffer $(300 \mathrm{mmol}$ $\mathrm{L}^{-1} \mathrm{NaOH}, 1 \mathrm{mmol} \mathrm{L}^{-1} \mathrm{Na}_{2}$ EDTA, pH 13.0) at $4{ }^{\circ} \mathrm{C}$ under dim light. After 20 min of denaturation, the slides were randomly placed in the horizontal gelelectrophoresis tank, facing the anode. Electrophoresis at $25 \mathrm{~V}$ and $300 \mathrm{~mA}$ lasted another $20 \mathrm{~min}$. After the electrophoresis, the slides were washed with a neutralisation buffer $\left(0.4 \mathrm{~mol} \mathrm{~L}^{-1}\right.$ Tris- $\left.\mathrm{HCl}, \mathrm{pH} 7.5\right)$ three times at five-minute intervals. The slides were stained with ethidium bromide $\left(20 \mu \mathrm{g} \mathrm{mL}^{-1}\right)$ and examined using a 250x magnification fluorescence microscope (Zeiss, Germany) equipped with an excitation filter of $515 \mathrm{~nm}$ to $560 \mathrm{~nm}$ and a barrier filter of $590 \mathrm{~nm}$. A total of 50 comets per sample per animal were scored ( 25 from each of two replicate slides) and pooled for each group of five animals (totalling 250 per group). Random fields were selected at a constant depth of the gel, avoiding the edges, and occasional dead cells and comets were captured with a black and white camera. The microscope image was transferred to a computer-based image analysis system (Comet Assay II, Perceptive Instruments Ltd. Suffolk, UK) and three main comet parameters were evaluated: tail length (expressed in micrometers), tail intensity (DNA \% in the comet tail), and tail moment.

\section{Statistical analysis}

For statistical analysis we used Statistica ${ }^{\circledR} 7.0$ (StatSoft, Tulsa, USA). Each sample was characterised for the extent of DNA damage with the mean ( \pm standard error of the mean), median, and range of the comet parameters measured. Moreover, cells were classified as either "damaged" or "undamaged" in respect to the threshold level for a long-tailed nucleus (LTN), i.e. the length over the $95^{\text {th }}$ percentile of the distribution of the tail lengths among controls (42). We used logarithmic transformation to normalise the distribution and equalise variances. Multiple comparisons between groups were performed on log-transformed data using the analysis of variance (ANOVA). The chi-square test was used for the statistical evaluation of LTN comet frequency. The level of statistical significance was set at $\mathrm{P}<0.05$.

\section{RESULTS}

\section{Peripheral blood leukocyte count}

Total leukocyte counts in mice are reported in Figure 1. Animals that were pre-treated with either natural and synthetic radioprotectors were less sensitive to the adverse effects of whole-body irradiation. Postirradiation therapy, however, insignificantly increased total leukocyte counts compared to negative control.

EEP and quercetin showed an acceptable toxicity profile compared to the synthetic radioprotector AET, which caused a drop in total leukocyte count in nonirradiated mice. This value was significantly lower than in non-irradiated mice that received EEP $(\mathrm{P}=0.048)$ or quercetin $(\mathrm{P}=0.015)$. In contrast to AET, EEP and quercetin slightly increased the total leukocyte count in non-irradiated mice, but these differences were not statistically significant (Figure 1).

Overall, quercetin showed better protective properties than EEP, both in pre-treatment and in therapy, and it also activated a higher number of leukocytes in non-irradiated mice.

\section{Primary DNA damage in leukocytes}

Figure 2 shows the results of the alkaline comet assay expressed as percentage of comets with long tailed nuclei (LTN/\%). The lowest LTN frequency was observed in mice pre-treated with quercetin; it differed significantly from all other samples (Figure 2). In contrast, pre-treatment with synthetic radioprotector AET had the highest LTN frequency. As for post-irradiation therapy, LTN frequency was similar to negative and solvent controls, save for quercetin-treated mice, and ranged as follows: EEP $<$ AET $<$ quercetin. None of the tested compounds induced a significant increase in LTN frequency in non-irradiated mice. Overall, quercetin showed better protective properties in pre-treatment, and EEP in post-irradiation therapy. On the other hand, AET induced a significant increase in primary DNA damage when given as pre-tretment, and a slight increase as post-irradiation therapy (Figure 2).

Table 1 shows the descriptive statistics and detailed inter-group comparisons for the comet tail lengths, tail intensities ( $\%$ tDNA), and tail moments measured in mouse leukocytes. Whole-body irradiation with 4 Gy significantly increased leukocyte primary DNA damage in respect to non-irradiated mice. However, irradiated mice pre-treated with either EEP or quercetin showed lower tail length, tail intensity, and tail moment. Quercetin was more effective than EEP, and both were less genotoxic than AET. The mice given post-irradiation therapy with EEP showed a slightly, but not significantly lower primary DNA damage than negative controls. In contrast, quercetin and AET increased all three comet parameters. In 


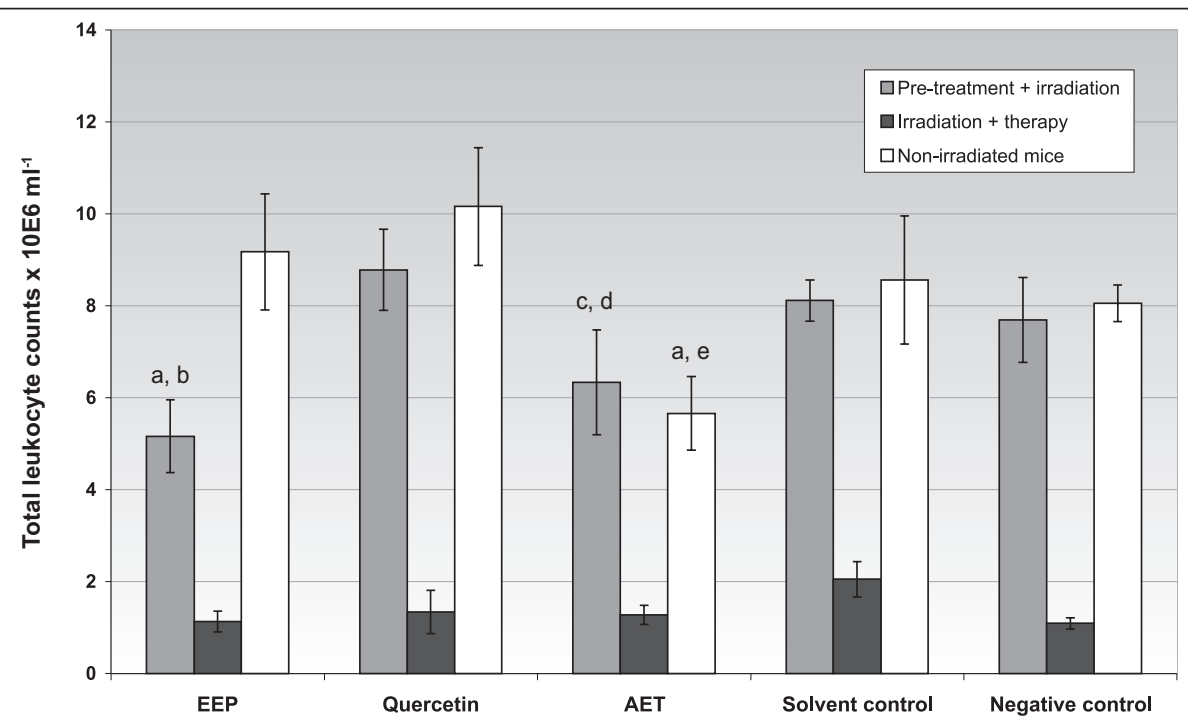

Figure 1 Peripheral blood leukocyte counts (mean $\pm S E$ ) in CBA mice receiving EEP, quercetin, AET, solvent, or saline (negative control) for three consecutive days before or after whole-body irradiation with gamma-rays (4 Gy) and in non-irradiated mice receiving the same (pre)treatment.

Note: inter-group comparisons were performed using ANOVA with post-hoc Duncan test. Significantly increased values $(P<0.05)$ are: $a$-compared to mice given quercetin; $b$ - compared to mice given AET; $c$-compared to solvent control; $d$-compared to negative control; $e$-compared to mice given EEP.

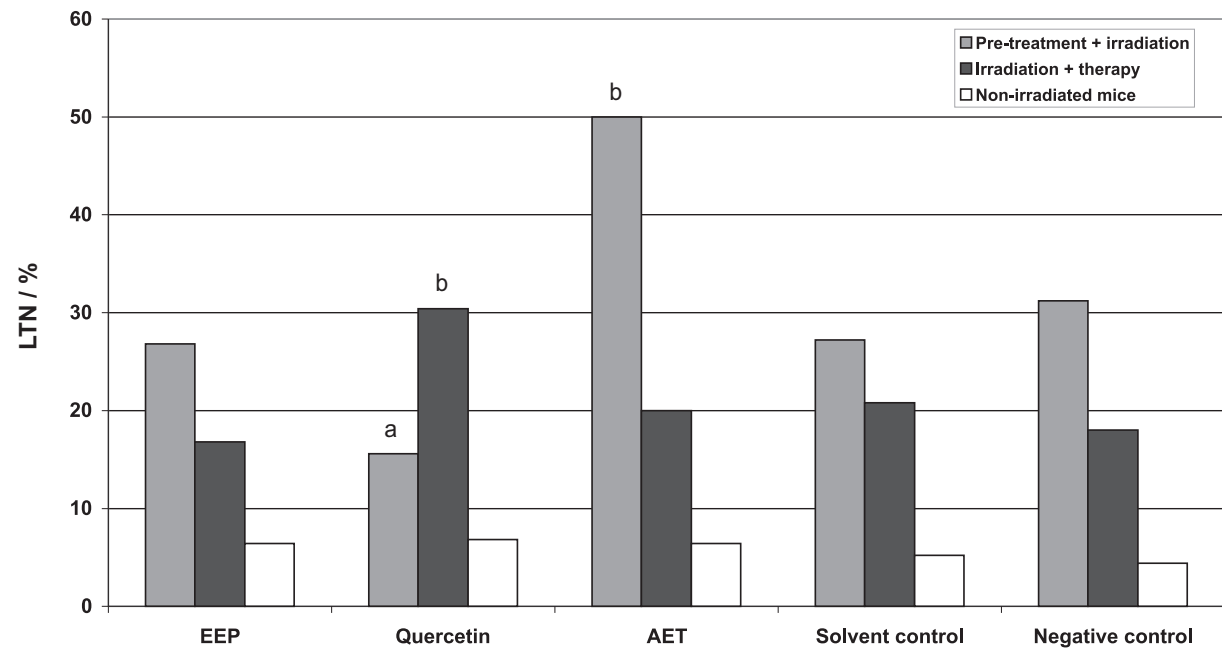

Figure 2 Results of the alkaline comet assay expressed as percentage of comets with long tailed nuclei (LTN/\%) measured in peripheral blood leukocytes of CBA mice receiving EEP, quercetin, AET, solvent, or saline (negative control) for three consecutive days before or after whole-body irradiation with gamma-rays (4 Gy) and in non-irradiated mice receiving the same (pre)treatment.

Note: inter-group comparisons were performed using the chi-square test. Statistical significance was set at $P<0.05$. $a$ - significantly lower than all other samples; $b$ - significantly higher than all other samples

non-irradiated mice, neither EEP nor quercetin were genotoxic in concentrations tested. AET, on the other hand, caused a slight but not significant increase in all three parameters.

\section{DISCUSSION}

One of the major challenges in cancer research is to discover non-toxic, selective, and effective 
Table 1 Results of the alkaline comet assay expressed as percentage of comets with long tailed nuclei (LTN\%) measured in peripheral blood leukocytes of CBA mice receiving EEP, quercetin, AET, solvent, or saline (negative control) for three consecutive days before or after whole-body irradiation with gamma-rays (4 Gy) and in non-irradiated mice receiving the same (pre)treatment.

\begin{tabular}{|c|c|c|c|c|c|c|c|c|c|}
\hline \multirow{3}{*}{ Group } & \multicolumn{9}{|c|}{ Comet parameters } \\
\hline & \multicolumn{3}{|c|}{ Tail length / $\mu \mathrm{m}$} & \multicolumn{3}{|c|}{ Tail intensity / \% tDNA } & \multicolumn{3}{|c|}{ Tail moment } \\
\hline & Mean $\pm \mathbf{S E}$ & Median & Range & $\begin{array}{c}\text { Mean } \pm \\
\text { SE } \\
\end{array}$ & Median & Range & Mean \pm SE & Median & Range \\
\hline \multicolumn{10}{|c|}{ Pre-treatment / gamma-irradiation } \\
\hline EEP & $16.72 \pm 0.20^{*}$ & 16.03 & 10.90 to 29.49 & $4.15 \pm 0.30$ & 2.53 & 0 to 33.43 & $0.52 \pm 0.04$ & 0.34 & 0 to 4.50 \\
\hline Quercetin & $15.53 \pm 0.18 *$ & 14.74 & 9.62 to 26.92 & $2.87 \pm 0.25^{*}$ & 1.62 & 0 to 30.05 & $0.35 \pm 0.03 *$ & 0.2 & 0 to 2.70 \\
\hline AET & $18.47 \pm 0.22$ & 18.27 & 10.26 to 31.41 & $3.21 \pm 0.22$ & 2.03 & 0 to 24.41 & $0.46 \pm 0.03$ & 0.31 & 0 to 3.29 \\
\hline $\begin{array}{l}\text { Solvent } \\
\text { control }^{\text {a }}\end{array}$ & $16.92 \pm 0.30$ & 15.38 & 9.62 to 41.02 & $4.00 \pm 0.31$ & 2.25 & 0 to 30.75 & $0.54 \pm 0.04$ & 0.28 & 0 to 3.94 \\
\hline $\begin{array}{l}\text { Negative } \\
\text { control }\end{array}$ & $18.57 \pm 0.40$ & 16.67 & 12.18 to 54.49 & $3.44 \pm 0.28$ & 1.99 & 0 to 35.62 & $0.49 \pm 0.04$ & 0.26 & 0 to 6.62 \\
\hline \multicolumn{10}{|c|}{ Gamma-irradiation / therapy } \\
\hline EEP & $17.04 \pm 0.36$ & 15.38 & 10.90 to 44.87 & $4.08 \pm 0.36$ & 1.67 & 0 to 39.84 & $0.56 \pm 0.05$ & 0.22 & 0 to 4.90 \\
\hline Quercetin & $23.04 \pm 0.95^{*}$ & 16.99 & 10.90 to 85.90 & $5.93 \pm 0.46$ & 3.11 & 0 to 39.52 & $0.98 \pm 0.09$ & 0.42 & 0 to 6.60 \\
\hline AET & $18.38 \pm 0.54$ & 15.38 & 10.26 to 52.56 & $4.75 \pm 0.50$ & 1.44 & 0 to 47.40 & $0.79 \pm 0.09$ & 0.19 & 0 to 8.34 \\
\hline $\begin{array}{l}\text { Solvent } \\
\text { control }^{\text {a }}\end{array}$ & $18.26 \pm 0.41$ & 16.03 & 11.54 to 50.00 & $4.43 \pm 0.46$ & 1.75 & 0 to 48.56 & $1.37 \pm 0.52$ & 0.25 & 0 to 9.82 \\
\hline $\begin{array}{l}\text { Negative } \\
\text { control }\end{array}$ & $18.01 \pm 0.53$ & 15.06 & 10.26 to 53.85 & $4.62 \pm 0.59$ & 1.34 & 0 to 49.84 & $0.78 \pm 0.12$ & 0.17 & 0 to 12.46 \\
\hline \multicolumn{10}{|c|}{ Non-irradiated mice } \\
\hline EEP & $13.35 \pm 0.08$ & 13.46 & 10.26 to 17.31 & $1.41 \pm 0.17$ & 0.53 & 0 to 24.18 & $0.16 \pm 0.02$ & 0.07 & 0 to 2.48 \\
\hline Quercetin & $13.75 \pm 0.10$ & 13.46 & 9.62 to 18.59 & $1.12 \pm 0.15$ & 0.30 & 0 to 24.18 & $0.13 \pm 0.02$ & 0.05 & 0 to 1.91 \\
\hline AET & $14.19 \pm 0.14$ & 14.10 & 9.62 to 22.44 & $2.18 \pm 0.27$ & 0.63 & 0 to 32.08 & $0.27 \pm 0.03$ & 0.08 & 0 to 3.70 \\
\hline $\begin{array}{l}\text { Solvent } \\
\text { control }^{\text {a }}\end{array}$ & $12.43 \pm 0.09$ & 12.50 & 9.62 to 15.38 & $1.32 \pm 0.26$ & 0.30 & 0 to 59.54 & $0.13 \pm 0.02$ & 0.04 & 0 to 3.43 \\
\hline $\begin{array}{l}\text { Negative } \\
\text { control }\end{array}$ & $13.49 \pm 0.09$ & 13.46 & 9.62 to 20.51 & $1.13 \pm 0.15$ & 0.29 & 0 to 16.24 & $0.13 \pm 0.02$ & 0.04 & 0 to 1.60 \\
\hline
\end{tabular}

Note: EEP and quercetin were given to mice in ip daily doses of $100 \mathrm{mg} \mathrm{kg}^{-1}$ and AET in ip doses of $281 \mathrm{mg} \mathrm{kg}^{-1}$ body weight. ${ }^{a}$ Ethanol (1\%); 250 comets per group (50 per animal) were measured; ${ }^{*} p<0.05$ compared with negative control (ANOVA)

cytoprotective compounds that would preferentially protect normal tissues during radiotherapy or chemotherapy. These compounds should be effective against genetic damage, mutation, changes to the immune system, and teratogenic effects.

In this study, we investigated radioprotective potentials of two natural compounds that were administered to mice before and after whole-body irradiation with gamma-rays. Ethanolic extract of propolis (EEP) contains a high proportion of bioactive lipophilic compounds such as flavones, flavonols and flavanones, and is widely used in traditional medicine (34). Quercetin is at the moment one of the most investigated and biologically effective polyphenols $(12,23)$. Here we report the results obtained with one dose of either compound (100 $\left.\mathrm{mg} \mathrm{kg}^{-1}\right)$, which was based on the positive findings of our previous studies $(10-12,27,31)$. In future studies we will investigate a broader range of doses.

Although exposure to ionising radiation involves different types of irradiation, this study focused only on adverse effects observed after external exposure to gamma-irradiation. Similar to gamma-rays are $\mathrm{X}$-rays, and both are classified as highly penetrating. $\mathrm{X}$-rays and gamma rays have the same effect on cells. $\mathrm{X}$-rays were the first form of photon radiation to be used to treat cancer. Nowadays, exposure to X-rays is mainly limited to diagnostic medicinal procedures, while gamma-rays are mostly used in radiotherapy and other more sophisticated methods (43). A typical 
dose for a solid epithelial tumor may range from $50 \mathrm{~Gy}$ to $70 \mathrm{~Gy}$ or more, given in daily doses that in adults usually range from 1.8 Gy to 2 Gy per fraction (44). Considering the inter-species differences between mice and humans, especially regarding the lethal dose of irradiation (45), in this study we selected the radiation dose of 4 Gy because affirmative results with 9 Gy prompted us to investigate a dose which corresponds more to a real therapeutic dose for humans.

Since mice received whole-body irradiation, the genotoxic effects of ionising radiation were studied in white blood cells, which circulate throughout the body and which have been confirmed as useful biodosimeters by many radiation studies $(46,47)$. The alkaline comet assay was selected as a sensitive method for detecting DNA damage in vivo and in vitro (ranging from single- and double-strand breaks in DNA to DNA base modifications, oxidative damage, and alkali-labile lesions) produced by known or potentially genotoxic substances (48-50).

When interacting with living matter, ionising radiation deposits energy that injures or destroys cells in the treated area. Absorbed radiation damages DNA, making it impossible for cells to grow. Even though radiation affects both cancer cells and normal cells, the latter can repair themselves and function properly. Irradiation in small divided doses allows enough time for healthy cells to repair the damage and continue to grow. However, cells with a diminished ability to repair sub-lethal damage (for example undifferentiated cancer cells) and cells with inherited or accumulated DNA damage will die or reproduce more slowly (44).

Our results demonstrate that acute exposure to gamma-irradiation significantly affected the levels of primary DNA damage in the leukocytes of CBA mice. One of the most important observations is that both EEP and quercetin administered to mice before whole-body irradiation were more effective in reducing primary DNA damage in leukocytes than the well-established chemical radioprotector AET (used as positive control). Although AET proved effective in some studies (35-37), its toxicity/genotoxicity seriously questions the reasons for its regular use. In contrast, the genotoxicity of EEP and quercetin is acceptably low, as evidenced by leukocyte DNA damage in non-irradiated mice in our study. We can conclude that quercetin is superior as a radioprotector when administered as pre-treatment, while EEP showed better results when given as therapy. These results have been supported by findings of other authors. Namely, quercetin itself possesses DNA damaging potential and generates free radicals (20, 23). When given to mice a few days before irradiation, it generated oxidative radicals and produced low levels of DNA damage, gradually stimulating DNA repair mechanisms which in turn counteracted the damage inflicted by ionising radiation. Therefore, low doses of quercetin potentiate an adaptive response in mice leukocytes, making them more resistant to acute irradiation. Similar results were reported by Oliveira et al. (20), who studied and confirmed adaptive response induced by quercetin in V79 cells in vitro.

In contrast, pre-treatment with EEP, which is a mixture of lipophilic compounds with remarkable free-radical scavenging properties, was not as effective as quercetin. It is possible that, due to complex composition, the pro-oxidative properties of quercetin are surpressed by other constituents. However, when given after irradiation, this complex composition contributed to a better recovery of irradiated cells and to a more efficient repair of radiation-inflicted DNA damage in mice.

The exact mechanism of protective action of propolis and related flavonoids against lethal effects of acute whole-body irradiation in mice is not known. Montoro et al. (8) established dose-dependent radioprotective effects of a propolis extract against DNA damage induced by gamma-radiation doses of ( 0.25 to 5$)$ Gy in vitro. Our study has shown that acute exposure to gamma-radiation significantly reduces leukocyte count in peripheral blood of mice. However, both pre-treatment and therapy with natural compounds, especially quercetin, efficiently protected the mice against the adverse effects of ionising radiation and also increased leukocyte count in nonirradiated mice. Several immunomodulators, including propolis and propolis-derived components, stimulate hemopoietic recovery and enhance the survival of irradiated animals (10). Reports of other authors (51, 52) confirm the protective effect of propolis on bone marrow and lymphoid tissues of mice treated with cytotoxic drugs. Immune activity boosted by propolis and related compounds enhances haemopoietic regeneration and survival following radiation-induced lympho- and myelo-supression (10).

In conclusion, our research conducted so far suggests that EEP and quercetin are effective and non-toxic radioprotectors with a potential to be used in supportive therapy in humans, as proposed elsewhere (53). However, further research is necessary before implementation in human protection against ionising 
radiation, especially in the treatment of cancer patients exposed to radiotherapy.

\section{Acknowledgements}

This study was supported by the Ministry of Science, Education and Sports of the Republic of Croatia (grants no. 119-70-1255 and 022-0222148-2137).

\section{REFERENCES}

1. Sankaranarayanan K. Estimation of the genetic risks of exposure to ionizing radiation in humans: current status and emerging perspectives. J Radiat Res 2006;47(Suppl B):B5766.

2. Karbownik M, Reiter RJ. Antioxidative effects of melatonin in protection against cellular damage caused by ionising radiation. Proc Soc Exp Biol Med 2000;225:9-22.

3. Kopjar N, Miočić S, Ramić S, Milić M, Viculin T. Assessment of the radioprotective effects of amifostine and melatonin on human lymphocytes irradiated with gama-rays in vitro. Arh Hig Rada Toksikol 2006;57:155-63.

4. Hensley ML, Schuchter LM, Lindley C, Meropol NJ, Cohen GI, Broder G, Gradishar WJ, Green DM, Langdon RJ, Jr, Mitchell RB, Negrin R, Szatrowski TP, Thigpen JT, Von Hoff D, Wasserman TH, Winer EP, Pfister DG. American Society of Clinical Oncology Clinical practice guidelines for the use of chemotherapy and radiotherapy protectants. J Clin Oncol 1999; 17:3333-55.

5. Uma Devi P, Bishit KS, Vinitha M. A comparative study of radioprotection by Ocimum flavonoids and synthetic aminothiol protectors in the mouse. Brit J Radiol 1998;71:782-4

6. Varanda EA, Tavares DC. Radioprotection: mechanisms and radioprotective agents including honeybee venom J Venom Anim Toxins 1998; 4:5-21.

7. Hosseinimehr SJ, Tavakoli H, Pourheidari G, Sobhani A, Shafiee A. Radioprotective effects of citrus extract against gamma-irradiation in mouse bone marrow cells. J Radiat Res 2003;44:237-41.

8. Montoro A, Almonacid M, Serrano J, Saiz M, Barquinero F, Barrios L, Verdú G, Pérez J, Villaescusa JI. Assessment by cytogenetic analysis of the radioprotection properties of propolis extract. Radiat Prot Dosim 2005;115:461-4.

9. Chaudhary P, Shukla SK, Kumar IP, Namita I, Afrin F, Sharma RK. Radioprotective properties of apple polyphenols: An in vitro study. Mol Cell Biochem 2006;288:37-46.

10. Oršolić N, Benković V, Horvat-Knežević A, Kopjar N, Kosalec I, Bakmaz M, Mihaljević Z, Bendelja K, Bašić I. Assessment by survival analysis of the radioprotective properties of propolis and its polyphenolic compounds. Biol Pharm Bull 2007;30:946-51

11. Benković V, Oršolić N, Horvat-Knežević A, Ramić S, Đikić D, Bašić I, Kopjar N. Evaluation of the radioprotective effects of propolis and flavonoids in gamma-irradiated mice: the alkaline comet assay study. Biol Pharm Bull 2008;31:167-72.

12. Benković V, Horvat-Knežević A, Đikić D, Lisčić D, Oršolić N, Bašić I, Kosalec I, Kopjar N. Radioprotective effects of propolis and quercetin in $\gamma$-irradiated mice evaluated by the alkaline comet assay. Phytomedicine 2008;15:851-8.
13. Manach C, Williamson G, Morand C, Scalbert A, Rémésy C. Bioavailability and bioefficacy of polyphenols in humans. I. Review of 97 bioavailability studies. Am J Clin Nutr 2005;81(Suppl 1):230S-42S.

14. Yang CS, Landau JM, Huang MT, Newmark HL. Inhibition of carcinogenesis by dietary polyphenolic compounds. Annu Rev Nutr 2001;21:381-406.

15. Nijveldt RJ, van Nood E, van Hoorn DE, Boelens PG, van Norren K, van Leeuwen PA. Flavonoids: a review of probable mechanisms of action and potential applications - Review. Am J Clin Nutr 2001;74:418-25.

16. Russo A, Acquaviva R, Campisi A, Sorrenti V, Di Giacomo C, Virgata G, Barcellona ML, Vanella A. Bioflavonoids as antiradicals, antioxidants and DNA cleavage protectors. Cell Biol Toxicol 2000;16:91-8.

17. Hollman PC, Katan MB. Dietary flavonoids: intake, health effects and bioavailability. Food Chem Toxicol 1999;37:93742.

18. Heim KE, Tagliaferro AR, Bobilya DJ. Flavonoid antioxidants: chemistry, metabolism and structure activity relationships. J Nutr Biochem 2002;13:572-84.

19. Horvathova K, Novotny L, Vachalkova A. The free radical scavenging activity of four flavonoids determined by the comet assay. Neoplasma 2003;50:291-5.

20. Oliveira NG, Rodrigues AS, ChavecaT, Rueff J. Induction of an adaptive response to quercetin, mitomycin $\mathrm{C}$ and hydrogen peroxide by low doses of quercetin in V79 Chinese hamster cells. Mutagenesis 1997;12:457-62.

21. Saito A, Sugisawa A, Umegaki K, Sunagawa H. Protective effects of quercetin and its metabolites on $\mathrm{H}_{2} \mathrm{O}_{2}$-Induced chromosomal damage to WIL2-NS cells. Biosci Biotechnol Biochem 2004;68:271-6.

22. Quercetin. In: IARC Monographs on the evaluation of carcinogenic risks to humans. Vol. 73, Some chemicals that cause tumours of the kidney or urinary bladder in rodents and some other substances. Lyon: IARC; 1999. p. 497-515.

23. Okamoto T. Safety of quercetin for clinical application (Review). Int J Mol Med 2005; 16:275-8.

24. Bankova V. Chemical diversity of propolis and the problem of standardization. J Ethnopharmacol 2005;100:114-7.

25. Heim KE, Tagliaferro AR, Bobilya DJ. Flavonoid antioxidants: chemistry, metabolism and structure activity relationships. J Nutr Biochem 2002;13:572-84.

26. Galati G, Sabzevari O, Wilson JX, O`Brien PJ. Prooxidant activity and cellular effects of the phenoxyl radicals of dietary flavonoids and other poliphenolics. Toxicology 2002;177:91104.

27. Oršolić N, Horvat-Knežević A, Bašić I. Propolis as a new potential immunomodulator in mice: antimetastatic activity of a water-soluble derivate of propolis (WSDP). Mellifera 2002;2:29-46

28. Sforcin JM. Propolis and immune system: a review. J Ethnopharmacol 2007;113:1-14.

29. Chen CN, Weng MS, Wu C-L, Lin JK. Comparison of radical scavenging activity, cytotoxic effects and apoptosis induction in human melanoma cells by Taiwanese propolis from different sources. eCAM 2004;1:175-85.

30. El-khawaga OA, Salem TA, Elshal MF. Protective role of Egyptian propolis against tumor in mice. Clin Chim Acta 2003;338:11-6. 
31. Oršolić N, Bašić I. Immunomodulation by water-soluble derivative of propolis (WSDP) a factor of antitumor reactivity. J Ethnopharmacol 2003;84:265-73.

32. Nijveldt RJ, van Nood E, van Hoorn DE, Boelens PG, van Norren K, van Leeuwen PA. Flavonoids: a review of probable mechanisms of action and potential applications - Review. Am J Clin Nutr 2001;74:418-25.

33. Russo A, Acquaviva R, Campisi A, Sorrenti V, Di Giacomo C, Virgata G, Barcellona ML, Vanella A. Bioflavonoids as antiradicals, antioxidants and DNA cleavage protectors. Cell Biol Toxicol 2000;16:91-8.

34. Kosalec I, Bakmaz M, Pepeljnjak S, Vladimir-Knezevic S. Quantitative analysis of the flavonoids in raw propolis from northern Croatia. Acta Pharm 2004;54:65-72.

35. Sverdlov AG, Mozzhukhin AS, Pavlova LM, Nikanorova NG. Chemical protection against neutron injury. Radiobiology 1969;9:706-10.

36. Antoku S, Sawada S. Comparative protective effect of AET against fast neutron and X-ray irradiation on mortality, intestinal disorders and hematopoietic injuries in mice. J Radiat Res 1970;11:70-8.

37. Grachev SA, Sverdlov AG. Chemical protection against $\mathrm{X}$-ray, gamma, and neutron radiation. In: Meyers J, editor. Armed forces radiobiology research institute contract report AFRRI CR 97-1. Bethesda (ML): AFRRI Information Services Division; 1997. p. 32.

38. Zakon o dobrobiti životinja [Animal Welfare Act, in Croatian]. Narodne novine 1999;19:505-10.

39. Institute of Laboratory Animals Resources (ILAR). Guide for the Care and Use of Laboratory Animals. Washington (DC): National Academy Press; 1996.

40. Doeing DC, Borowicz JL, Crockett ET. Gender dimorphism in differential peripheral blood leukocyte counts in mice using cardiac, tail, foot, and saphenous vein puncture methods. BMC Clin Pathol 2003;3:3 [displayed 17 March 2009]. Available at http://www.biomedcentral.com/14726890/3/3.

41. Singh NP, McCoy MT, Tice RR, Schneider LL. A simple technique for quantitation of low levels of DNA damage in individual cells. Exp Cell Res 1988;75:184-91.

42. Betti C, Davini T, Giannessi L, Loprieno N, Barale R. Microgel electrophoresis assay (comet test) and SCE analysis in human lymphocytes from 100 normal subjects. Mutat Res 1994;307:323-33.

43. National Cancer Institute. Radiotherapy [displayed 25 November 2008]. Available at http://cancerweb.ncl.ac.uk/ cancernet/600071.html.

44. Gamulin M, Garaj-Vrhovac V, Kopjar N. Evaluation of DNA damage in radiotherapy-treated cancer patients using the alkaline comet assay. Coll Antropol 2007;31:837-45.

45. Levin SG, Young RW, Stohler RL. Estimation of median human lethal radiation dose computed from data on occupants of reinforced concrete structures in Nagasaki, Japan. Health Phys 1992;63:522-31.

46. Bender MA, Awa AA, Brooks AL, Evans HJ, Groer PO, Littlefield LG, Pereira C, Preston J, Wachholz BW. Current status of cytogenetic procedures to detect and quantify previous exposure to radiation. Mutat Res 1988;196:10359.

47. International Atomic Energy Agency (IAEA). Cytogenetic analysis for radiation dose assessment. Technical Report Series 405. Vienna: IAEA; 2001.

48. Olive PL. DNA damage and repair in individual cells: applications of the comet assay in radiobiology. Int J Radiat Biol 1999;75:395-405.

49. Tice RR, Agurel E, Burlinson B, Hartman A, Kobayshi H, Miyamae Y, Rojas E, Ryu JC, Sasaki YF. Single cell gel/comet assay: guidelines for in vitro and in vivo genetic toxicology testing. Environ Mol Mutagen 2000;35:206-21.

50. Collins AR. The comet assay for DNA damage and repair. Mol Biotechnol 2004;26:249-61.

51. Lahouel M, Boulkour S, Segueni N, Fillastre JP. Protective effect of flavonoides against the toxicity of vinblastine, cyclophoshamide and paracetamol by inhibition of lipidperoxydation and increase of liver glutathione. Pathol Biol 2004;52:314-22.

52. Sadzuka Y, Sugiyama T, Shimoi K, Kinae N, Hirota S. Protective effect of flavonoids on doxorubicin-induced cardiotoxicity. Toxicol Lett 1997;92:1-7.

53. Ribeiro LR, Salvadori DMF. Dietary components may prevent mutation-related diseases in humans. Mutat Res 2003;544:195-201. 
Sažetak

PRIMJENA ALKALNOG KOMETNOG TESTA U ISTRAŽIVANJU RADIOPROTEKTIVNIH UČINAKA ALKOHOLNOG EKSTRAKTA PROPOLISA I KVERCETINA NA MIŠEVIMA OZRAČENIM GAMA-ZRAČENJEM

$\mathrm{Na}$ miševima soja CBA istraženi su radioprotektivni učinci alkoholnog ekstrakta propolisa (AEP) i flavonoida kvercetina primijenjenih u obliku predtretmana i terapije usporedo s izlaganjem gama-zračenju iz izvora ${ }^{60} \mathrm{Co}$, doze $4 \mathrm{~Gy}$. Testirane tvari injicirane su miševima intraperitonealno u dozi od $100 \mathrm{mg} \mathrm{kg}^{-1}$ tijekom tri uzastopna dana. Nakon završetka pokusa u uzorcima krvi ozračenih miševa utvrđen je ukupni broj leukocita, a razina primarnih oštećenja u DNA izmjerena je primjenom alkalnog kometnog testa. Usporedo su istraženi i mogući genotoksični učinci testiranih tvari na neozračenim miševima. Razine radioprotekcije koju pružaju propolis i kvercetin uspoređene su sa sintetskim radioprotektorom AET-om (S-(2-aminoetil)izotiouronij bromid hidrobromid). Predtretman miševa bilo kojim oblikom radioprotektora pridonosi boljem odgovoru na zračenje. U miševa koji su primili radioprotektore u obliku terapije uočen je mali porast ukupnog broja leukocita u odnosu na ozračenu negativnu kontrolu. Kvercetin je pružio bolju zaštitu od zračenja nego AEP, i u predtretmanu i terapiji, a u neozračenih miševa potaknuo je oslobađanje većeg broja leukocita u odnosu na negativnu kontrolu. Rezultati istraživanja upućuju na to da propolis i njegove flavonoidne sastavnice, osobito ako su primijenjene prije ozračivanja, mogu učinkovito zaštititi miševe od štetnih učinaka ionizirajućeg zračenja i smanjiti razinu primarnih oštećenja DNA u leukocitima. AEP i kvercetin u testiranim dozama nisu bili genotoksični, za razliku od AET-a koji je izazvao mali porast razine oštećenja DNA u leukocitima neozračenih miševa. Iako rezultati istraživanja upućuju na radioprotektivne učinke testiranih prirodnih spojeva, radi pojašnjenja pretpostavljenih mehanizama radioprotekcije potrebna su daljnja istraživanja.

KLJUČNE RIJEČI: alkalni kometni test, flavonoid, leukocit, oštećenja DNA, pčelinji proizvod, radioprotektor

\section{CORRESPONDING AUTHOR:}

\section{Vesna Benković, $\mathrm{PhD}$}

Department of Animal Physiology, Faculty of Science, University of Zagreb, Rooseveltov trg 6,

HR-10000 Zagreb, Croatia

E-mail: vesna@pmf.biol.hr 